\title{
TRANSFORMATION, ADAPTATION AND UNIVERSALISM
}

\section{Nadine Andrews}

\section{HighWire CDT Lancaster University}

\begin{abstract}
Global efforts to mitigate climate change are inadequate, making planning for adaptation to increases in temperature critically important. Adaptation comes in many forms, none of which are neutral. All responses have ethical and equity dimensions. With transformational adaptation, changes in values are likely. Looking ahead to 2100 , Heatley anticipates that universalism values will come under threat from the impacts of $3-4^{\circ} \mathrm{C}$ warming. But breakdown of solidarity and disruption of international systems of trade and security is already within sight: self-protection values and isolationist tendencies are gaining in salience.
\end{abstract}

Self-protection values and unrealistic optimism are discussed in this paper as defences against the profound psychological threat posed by climate change. The dominant cultural worldview of progressivism is rendered untenable: we are not in control of nature. The project of progress as it is currently conceptualised must be forgotten not just for a hundred years as Heatley pleads, but altogether, and an alternative idea of human flourishing promoted instead. But who are the custodians of values that help us live in more harmonious relationship with the natural world? Who can champion adaptation as universalism? This paper asks whether spiritual leaders will be able to step up and perform this role.

\section{Key words}

Transformation, adaptation, climate change, values, psychological threat, defence

May 2016 was the $13^{\text {th }}$ month in a row to break global temperature records, with 2016 set to become the hottest year ever recorded, completing a run of three record years in a row (Carrington 2016). Temperatures have risen by $1^{\circ} \mathrm{C}$ since pre-industrial times, and the symbolic milestone of 400 ppm of $\mathrm{CO} 2$ in the atmosphere has now been passed. As Heatley argues, optimism about preventing dangerous climate change is unrealistic. And it is diverting attention away from where it needs to be focussed: planning our adaptation to the $3-4^{\circ} \mathrm{C}$ increase that seems more likely, and acting to prevent even higher temperature increases.

I will discuss optimism later but first I respond to the issue of adaptation.

Adaptation begins with accepting the reality of the situation we are in. Acceptance enables us to make the psychological adjustments necessary for responding in ways appropriate to the new reality (Crompton \& Kasser 2009). But according to the Intergovernmental Panel on Climate Change's (IPCC's) most recent Assessment Report (AR5), maladaptation is a growing concern. There are many factors thought to be contributing to maladaptation, including different perceptions of risks, competing values, as well as assumptions that adaptation will be a rational-linear problem-free process (IPCC 2014 pp.187, 199), thereby underestimating the complexity of adaptation decisionmaking.

AR5 describes two types of adaptation: incremental and transformational. Incremental adaptation is often referred to as 'business-as-usual' because unlike transformational adaptation, it does not challenge or disrupt existing systems and structures. Given these are the systems that are contributing to climate change in the first place, how effective incremental adaptation can really be is doubtful. AR5 states that for avoiding intolerable risks "transformational adaptation may be required if incremental adaptation proves insufficient" (p.189). Based on the success of our 
mitigation track record to date, it's not a wild guess that incremental adaptation will indeed prove to be insufficient and that transformational adaptation will be needed. AR5 explains that transformational adaptation may be reactive, forced, induced by random factors or deliberately created through social and political processes (p1105). But however it happens, it is not a neutral process ( $p 1121$ ) and there are concerns about the equity and ethical dimensions ( $p 1105)$. Planning for transformational change will not be easy: there are many social, political and cultural and psychological barriers and resistances to changing the fundamental attributes of existing systems and structures, not least that it may pose a threat to vested interests (p1121). Even if we could reach agreement about what constitutes 'proof' of incremental adaptation insufficiency (which is a big 'if'), by the time this point of incontrovertible proof is reached, it will be too late to do much in the way of advance planning especially for transformations that are equitable and ethical.

Transformational adaptation is also likely to involve changes in values, although AR5 does not specify which ones. However, Heatley does in referring to universalism, which I discuss now.

Universalism values are to do with understanding, appreciation, tolerance and protection for the welfare of all people and for nature (Schwartz 1992). Universalism and benevolence, which is concerned with caring for in-group members, form a self-transcendence set of values beyond individual self-interest. In Schwartz's model (1992; Schwartz et al 2012), self-transcendence values are structured in the mind in an oppositional relationship with self-enhancement values. Selfenhancement values are to do with power over others, social status and prestige, and material and financial wealth. The oppositional nature means that when one set of values is activated in the mind, the other set is suppressed: it is difficult to think about and act from both sets of values at the same time. The more a value is activated, the stronger it becomes, and the easier it is to subsequently activate. This matters because universalism values are associated with ecologically responsible behaviour, whereas self-enhancement values are associated with lack of concern for the natural world (Schultz et al 2005; Bardi \& Schwartz 2003; Sheldon \& Kasser 2011). Self-enhancement values are anxiety-based: they are self-protective values pursued to cope with anxiety in situations of uncertainty (Schwarz et al 2012).

Looking ahead to 2100, Heatley anticipates that universalism values will come under threat from the impacts of $3-4^{\circ} \mathrm{C}$ warming. In the UK these impacts are likely to include the breakdown of systems and structures of globalisation upon which the UK depends, as a result of war and other security threats, mass migration, and the isolationist policies of other nations undermining collaborative universalism approaches. The fragile solidarity of the European Union (EU) may not survive the pressures, he warns. But we do not have to wait till 2100 for the breakdown of solidarity and disruption of international systems of trade and security. As we enter a post-Brexit world, it is already within sight. The self-protection values and isolationist tendencies that have been developing in the UK for some time have erupted to the surface, creating political chaos. The fear now is that this referendum result will spur on those in other EU countries with similar concerns, "making the disintegration of the EU practically irreversible" (Soros 2016).

Universalism values are already under threat. So why is it that self-protection values are becoming stronger in society? Climate change is a situation of huge uncertainty and poses profound existential threat. It threatens sense of safety, and stability and integrity of self-identity by threatening life plans and subverting internalised expectations of the future (Crompton \& Kasser 2009; Hamilton \& Kasser 2009; Weintrobe 2013; American Psychological Association 2009; Norgaard 2006; Lertzman 2015; Hoggett 2011). The human tendency is to alleviate the stress and anxiety caused by psychological threat through defence mechanisms and coping strategies (Cramer 1998).

One defence is to retreat into self-protection. But such a retreat is not a purely individual, personal response: defences are culturally sanctioned and maintained by social norms and structures (Randall 
2013). As a society, explains Macy (1993), "we are caught between a sense of impending apocalypse and an inability to acknowledge it" (p15). This allows individuals and institutions to simultaneously acknowledge climate change and its risks (e.g. COP21 pledges) and deny it (e.g. the pledges are below the level needed to restrain warming to within 2 degrees) in a process known as disavowal. Interestingly, a recent survey found that Brexit voters were more likely to deny that climate change is human caused (Vaughan 2016).

Another defence is unrealistic optimism. Optimism is often pursued because of a fear that to do otherwise would be to fall into despair. Despair, Macy (1993 p18) reminds us, "is tenaciously resisted because it represents a loss of control, an admission of powerlessness". This takes us to the issue of progress: climate change renders the dominant cultural worldview of progressivism untenable and this is profoundly threatening because progressivism is about being in control. Progressivism is the belief that is through advancement of technoscience, industrialisation and economic development that the human condition can be improved (Foster 2015). The presupposition is that humans are separate from, and superior to, nature. That we can transcend nature's limits, harness its forces and exploit its resources for our own ends (Plumwood 1993; Merchant 1983; Midgley 2003). It is exactly this cultural worldview that has led us to this situation of ecological crisis (e.g. White 1967; Bateson 1982; Plumwood 1993), and which is also hindering us from responding adaptively. We would do better to let go of such hubris and embrace humility, for we cannot technofix and economically develop our way out of this mess. That, as Wright (2004 p61) argues, is an 'ideological pathology'. We have to forget the project of progress as it is currently conceptualised, not just for a hundred years as Heatley pleads, but altogether, and promote an alternative idea of human flourishing that is infused with different values.

Adaptation should not become a purely local project motivated by narrow self-protection values: that is unlikely to end well for us or for the other living beings with whom we share the planet. But it is not clear who can champion an alternative vision of 'adaptation as universalism'. Who are the custodians of universalism values with sufficient socio-cultural influence to keep these values activated in public, media and political minds? Will spiritual leaders be able to step up and perform this role? The 2015 Papal Encyclical suggests this is Pope Francis' intention, with its fierce critique of capitalism and emphasis on the interconnectedness of humans with the rest of nature. In calling for a subject-subject relationship of mutuality rather than a subject-object relationship of domination and exploitation, Pope Francis echoes indigenous belief systems as expressed by for example the Indigenous Environmental Network ${ }^{1}$ who campaigned and protested at COP 21 in Paris. AR5 acknowledges that indigenous peoples' holistic view of community and environment is a major resource for adapting to climate change, but notes that such non-scientific sources of knowledge have not yet been used consistently in existing adaptation efforts $(p 26 ; 181)$. How and why is not explored but a clue is in the term 'non-scientific'. Letting go of ideologies of scientism and progressivism is surely part of the transformational change in existing structures and systems needed for living in more harmonious relationship with the natural world.

\section{References}

American Psychological Association, 2009. Psychology \& Global Climate Change: addressing a multifaceted phenomenon and set of challenges. Washington DC: American Psychological Association.

Andrews, N., Fahy, K. and Walker, S. 2016. "Between intention and action: psychosocial factors influencing action on climate change in organisations." In Innovation in Climate Change Adaptation, edited by W.F. Filho, 275-287. Cham: Springer International Publishing.

\footnotetext{
${ }^{1}$ see http://indigenousrising.org
} 
Bardi, A. \& Schwartz, S.H., 2003. Values and behaviour: strength and structure of relations.

Personality and Social Psychology Bulletin, 29, pp.1207-1220.

Bateson, G., 1982. Steps to an Ecology of Mind. Reprint 1987. Northvale, New Jersey: Jason Aronson Inc.

Carrington, D. (2016) Shattered records show climate change is an emergency today, scientists warn. theguardian.com. Available at <https://www.theguardian.com/environment/2016/jun/17/shatteredrecords-climate-change-emergency-today-scientists-warn> Accessed 18 June 2016

Cramer P., 1998. Coping and defense mechanisms: what's the difference? Journal of Personality, 66(6), pp.919-946.

Crompton, T. \& Kasser, T., 2009. Meeting environmental challenges: the role of human identity.

Godalming, UK: WWF-UK.

Foster, J., 2015. After Sustainability. London: Routledge.

Hamilton, C., and T. Kasser. 2009. "Psychological Adaptation to the Threats and Stresses of a Four Degree World." [conference paper] Four Degrees and beyond Conference, Oxford University, Oxford, UK, September 28-30. Hoggett, P., 2011. Climate change and the apocalyptic imagination. Psychoanalysis, Culture \& Society, 16 (Sept), pp.261-275.

IPCC. 2014. "Climate Change 2014 Impacts, Adaptation, and Vulnerability Part A: Global and Sectoral Aspects." Working Group II Contribution to the Fifth Assessment Report of the Intergovernmental Panel on Climate Change. New York, NY: Cambridge University Press. Lertzman, R., 2015. Environmental melancholia: psychoanalytic dimensions of engagement. East Sussex: Routledge.

Macy, J. 1993. World as Lover, World as Self. Berkeley: Parallax Press.

Merchant, C., 1983. The Death of Nature. San Francisco: Harper \& Row.

Midgley, M., 2003. Myths We Live By. London and New York: Routledge.

Norgaard, K.M., 2006. "People want to protect themselves a little bit": Emotions, denial, and social movement non- participation. Sociological Inquiry, 76(3), pp.372-396.

Plumwood, V., 1993. Feminism and the mastery of nature. London: Routledge.

Randall, R., 2013. Great expectations: the psychodynamics of ecological debt. In: S. Weintrobe, ed. Engaging With Climate Change: psychoanalytic and interdisciplinary perspectives. Hove UK:

Routledge. pp.87-102.

Schultz, P. W., V. V. Gouveia, L. D. Cameron, G. Tankha, P. Schmuck, and M. Franek. 2005. "Values and Their Relationship to Environmental Concern and Conservation Behavior." Journal of CrossCultural Psychology 36 (4): 457-475. doi:10.1177/0022022105275962. behaviour. Journal of CrossCultural Psychology, 36(4), pp.457-475.

Schwartz, S.H., 1992. Universals in the content and structure of values: theoretical advances and empirical tests in 20 countries. Advances in Experimental Social Psychology, 25, pp.1-65.

Schwartz, S. H. et al., 2012. Refining the theory of basic individual values. Journal of Personality and Social Psychology, 103(4), pp.663-88.

Sheldon, K.M. \& Kasser T., 2011. Americans Recommend Smaller Ecological Footprints When Reminded of Intrinsic American Values of Self-Expression, Family, and Generosity, Ecopsychology 3(2), pp.97-104.

Soros, G. 2016. Brexit and the future of Europe. Project-syndicate.org. Available at <https://www.project-syndicate.org/commentary/brexit-eu-disintegration-inevitable-by-georgesoros-2016-06> Accessed 26 June 2016

Vaughan, A. 2016. Brexit voters almost twice as likely to disbelieve in manmade climate change. Theguardian.com. Available at <https://www.theguardian.com/environment/2016/jun/16/brexitvoters-almost-twice-as-likely-to-disbelieve-in-manmade-climate-change> Accessed 17 June 2016 Weintrobe S. ed., 2013. Engaging With Climate Change: psychoanalytic and interdisciplinary perspectives. Hove, UK: Routledge.

White, L., 1967. The historical roots of our ecological crisis. Science, 155 (3767), pp.1203-1207. Wright. R., 2004. A Short History of Progress. Edinburgh: Canongate Books. 